\title{
Knapping methods and techniques in the bracelets quarry of Cortijo Cevico (Loja, Granada)
}

\author{
Francisco Martínez-Sevilla ${ }^{1}$, Antonio Morgado Rodríguez ${ }^{1}$, \\ Francisca Jiménez Cobos ${ }^{1}$, Mario Gutiérrez Rodríguez ${ }^{1}$, \\ Antonio López García ${ }^{2}$, José Antonio Lozano Rodríguez ${ }^{3}$, Javier Carrasco Rus ${ }^{1}$ \\ 1. Dpto. Prehistoria y Arqueología. Universidad de Granada, Spain. \\ Email: Martínez-Sevilla: martinezsevilla@ugr.es; Morgado Rodríguez: morgado@ugr.es; \\ Jiménez Cobos: franciscajimenezcobos@gmail.com; Gutiérrez Rodríguez: mario.gr.4@gmail.com; \\ Carrasco Rus: jcrus@ugr.es \\ 2. Real Academia de España en Roma, Italy. Email: antonio-lopez-garcia@hotmail.com \\ 3. Instituto Andaluz de Ciencias de la Tierra, CSIC-Universidad de Granada, Spain. Email: jalozano@ugr.es
}

\begin{abstract}
:
The stone bracelets are one of the most outstanding elements of personal ornaments of the ancient Neolithic in Western Mediterranean and the South of the Iberian Peninsula (5500-4800 cal. BCE). These bracelets are considered an element of cultural identity and a chronological marker of the first Neolithic societies in these areas. The study of the production processes of this ornament has brought a new approach to social relations of the early Neolithic groups of this area. The existence of specialized workshops and the circulation of these objects show the shift towards more complex social organizations. The aim of this paper is to present knapping methods and techniques carried out in the Neolithic bracelets quarry of the Cortijo Cevico. This quarry has recently been discovered and excavated, and it is the first site of its kind in the Iberian Peninsula. It is a rocky outcrop in the geological formation of Trías de Antequera, formed by dolomitic marbles. On this site we carried out the extraction works, as well as the first transformation of the knapping performs that were going to be processed as bracelets. In addition, we have applied for the first time in this paper the methodology consists on using diacritical schemes in the knapping waste of the bracelets. This methodology, along with experimentation and technical stigmas, has allowed the recognition of the techniques and methods applied to knapping dolomitic marbles and these are presented for the first time in this paper.
\end{abstract}

Keywords: stone bracelets; Neolithic; quarry; diacritical schemes; southern Iberian Peninsula

\section{Introduction}

The stone bracelets are one of the ornaments associated with the first Neolithic societies of the Western Mediterranean. These ornaments, and cardial and impressed ceramics are characteristic of these cultures. This phenomenon, that is the use of these ornaments, extends over different geographical areas of Europe: Northern Italy (Michelli 2012; Pétrequin et al. 2015), the French coast and the interior of France (Fromont 2013; Pailler 2007). In the Iberian

Published by the School of History, Classics and Archaeology, University of Edinburgh ISSN: 2055-0472. URL: http://journals.ed.ac.uk/lithicstudies/

This work is licensed under a Creative Commons Attribution 2.5 UK: Scotland License. 
Peninsula, the concentration of stone bracelets and their production contexts are located in the South as the original focus, and the Levant as the second geographical unit in the use of these ornaments. The chronology of stone bracelets in the Iberian Peninsula is similar to that of other cultural contexts of the Western Mediterranean. The bracelets appear during the Early Neolithic in different areas of Iberia with its peak in the Epicardial Neolithic, and it disappears in the Late Neolithic with the construction of the first megalithic monuments. In calibrated dates, the stone bracelets appear between the 5500-4800 BCE, being its maximum representation from 5300-5200 BCE (Martínez-Sevilla 2016: 497).

The waste out of the bracelets production is common in the workshop where they were elaborated (Martínez-Sevilla 2010; Martínez-Sevilla \& Salmerón 2014). However, the extraction quarries of raw materials are not recognizable so easy. In the case of France, with a long tradition in studies of prehistoric technology, only one quarry of this type has been documented (Fromont et al., 2006). It is an outcrop of schist, where the extraction and conformation of preforms, was carried out. The second example is the quarries of green stones (jade, serpentinite and amphibolite) located in the surroundings of the Mount Viso in the Italian Alps (Pétrequin et al., 2015). In this sense, the quarry of Cortijo Cevico is the only example of this type of site documented in the Iberian Peninsula at the moment. In this dolomitic marble quarry the extraction of the raw material and the knapping of preforms was conducted, that are the first step of bracelets production. The location of a quarry destined exclusively to the production of bracelets highlights the importance of these ornaments for this period. On the other hand, the study of the material record of the quarry has allowed us, for the first time, to classify different kinds of wastes relating to the early stages of bracelets production. The technological analysis of this waste has brought the identification of the knapping techniques and methods on a raw material never studied before in Western Europe.

\subsection{The quarry of Cortijo Cevico: Geographical, geological and archaeological context}

The quarry of Cortijo Cevico is located together with the highest concentration of sites with stone bracelets in the Southern of the Iberian Peninsula. This quarry is situated in the central part of Genil River basin in a pivotal point between the leading densities of bracelets (Figure 1). Given the nature of the quarry it has been impossible to date it by absolute chronology. However, its use must be restricted to the chronological distribution of the stone bracelets phenomenon. The few absolutes dates of bracelets workshops are located in chronologies from the $6^{\text {th }}$ to $5^{\text {th }}$ millennium BCE (Table 1 ).

The outcrop is located in the West of Granada, about four kilometres (to the West also) away from the village of Ventorros de San José (Loja), on Genil River right bank at the peak of the fluvial basin. The site is occupied by oaks and bushes and surrounded by olive trees (Figure 2.A). This is an area of grazing that has not been used for agriculture. From the geological point of view, the quarry is located in the northernmost part of the so-called Trías de Antequera. These geological materials are part of the triassic outcrops of the Subbetic, in the central sector of the outer zone of the Betic Cordillera. In Trías de Antequera, it appears a set of materials formed by a diapiric process (Foucault 1966; Pérez-López \& Pérez-Valera 2003; Sanz de Galdeano et al., 2008). This process generates the megabreccia of evaporitic rocks (gypsum complex), where it can be found inserted clasts and blocks from other Triassic units (sometimes not even Triassic), distinguished by a tectonic foliation in a matrix rich in gypsum. In Trías de Antequera, contrary to other Subbetian Triassic units, we can find decametric blocks from a variety of lithologies (mainly metamorphic rocks). These lithologies are exotic regarding to units from Triassic age. Fundamentally, these units of Triassic age of 'Germanic facies' are widely exposed in the NE-SW corridor, from Loja (Granada) to Antequera (Malaga). It consists of evaporitic rocks (gypsum, anhydrite and salt) and, to a 
lesser extent of carbonated rocks attributed to Cehegín Formation (Ladainian) and Zamoranos Formation (Norian), along with detrital siliciclastic units and belonging to the Keuper facies (Jaén Keuper Group) of the Kamian age (Pérez Valera 2005).

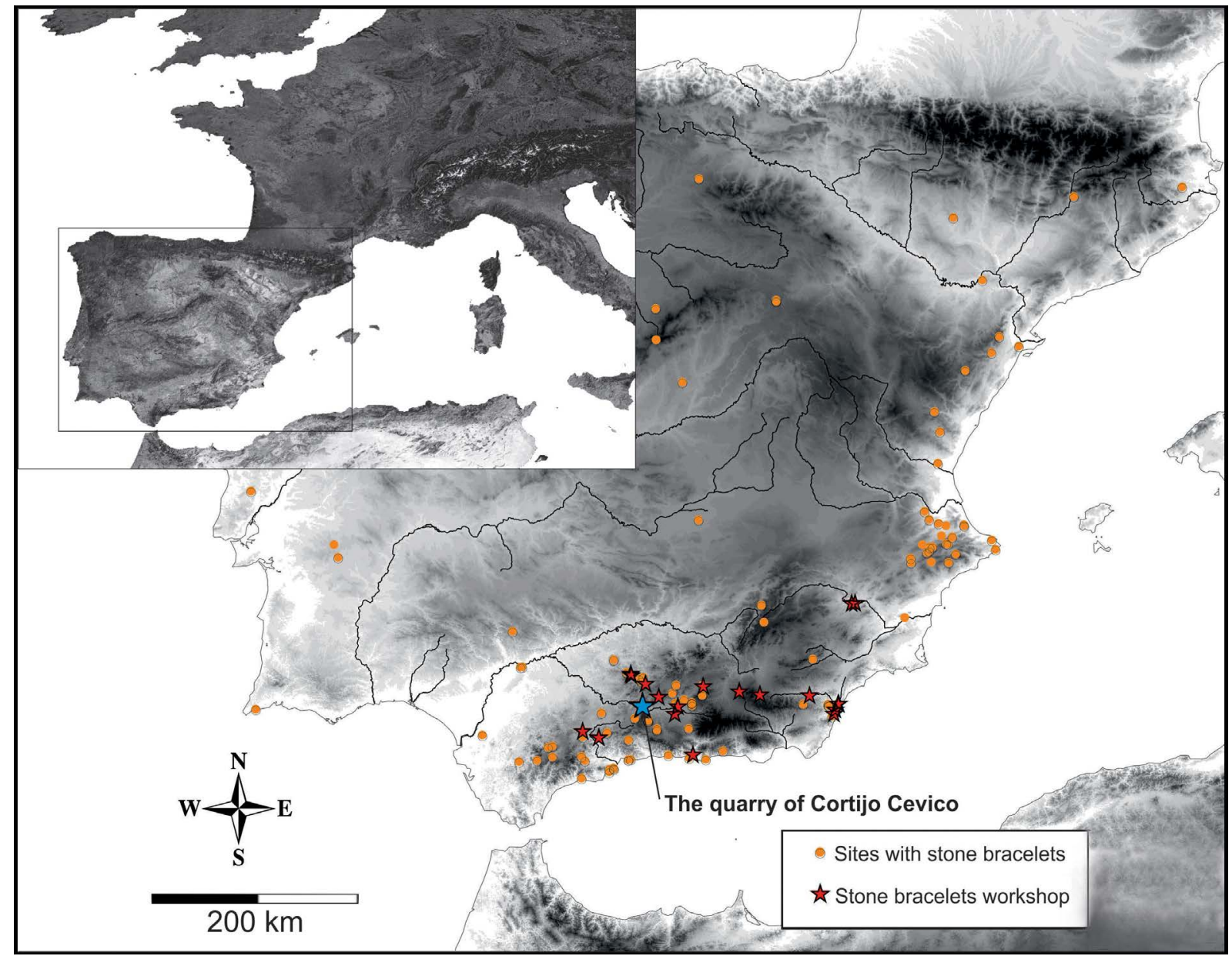

Figure 1. Situation of the quarry within the general context of stone bracelets and workshops.

Table 1. The most representatives absolute dates of the bracelets workshops in the south of the Iberian Peninsula.

\begin{tabular}{|c|c|c|c|c|c|c|}
\hline $\begin{array}{l}\text { Bracelets } \\
\text { workshop }\end{array}$ & Reference & Date (BP) & $\begin{array}{c}\text { cal. } 1 \sigma \\
\text { (BCE) }\end{array}$ & $\begin{array}{c}\text { cal. } 2 \sigma \\
\text { (BCE) }\end{array}$ & Type & Bibliography \\
\hline $\begin{array}{l}\text { Cueva de los } \\
\text { Mármoles }\end{array}$ & Beta-313471 & $6250 \pm 40$ & $5303-5211$ & $5315-5202$ & Cereal & $\begin{array}{l}\text { (Peña-Chocarro et al. } \\
\text { 2013) }\end{array}$ \\
\hline $\begin{array}{l}\text { Cueva de los } \\
\text { Mármoles }\end{array}$ & WK-25171 & $6198 \pm 31$ & $5169-5074$ & $5228-5049$ & Cereal & $\begin{array}{l}\text { (Peña-Chocarro et al. } \\
\text { 2013) }\end{array}$ \\
\hline $\begin{array}{l}\text { Cueva de los } \\
\text { Mármoles }\end{array}$ & Beta-313473 & $6180 \pm 30$ & $5173-5072$ & $5219-5038$ & Cereal & $\begin{array}{l}\text { (Peña-Chocarro et al. } \\
\text { 2013) }\end{array}$ \\
\hline $\begin{array}{l}\text { Cueva de los } \\
\text { Mármoles }\end{array}$ & WK-25171 & $6198 \pm 31$ & $5169-5074$ & $5228-5049$ & Cereal & (Carvalho et al. 2010) \\
\hline Cerro Virtud & Beta-101424 & $6160 \pm 80$ & $5214-5006$ & $5306-4908$ & Charcoal & (Ruiz \& Montero 1999) \\
\hline $\begin{array}{l}\text { Cabecicos } \\
\text { Negros }\end{array}$ & Beta-347627 & $6530 \pm 30$ & $5158-5044$ & $5196-5000$ & Seashell & $\begin{array}{l}\text { (Cámalich \& Martín } \\
\text { 2013) }\end{array}$ \\
\hline $\begin{array}{l}\text { Cabecicos } \\
\text { Negros }\end{array}$ & Beta-336255 & $6470 \pm 30$ & $5061-4958$ & $5142-4917$ & Seashell & $\begin{array}{l}\text { (Cámalich \& Martín } \\
\text { 2013) }\end{array}$ \\
\hline $\begin{array}{l}\text { Cabecicos } \\
\text { Negros }\end{array}$ & Beta-336258 & $6340 \pm 30$ & 4903-4805 & $4952-4760$ & Seashell & $\begin{array}{l}\text { (Cámalich \& Martín } \\
\text { 2013) }\end{array}$ \\
\hline
\end{tabular}





Figure 2. Geographical and geological context of the quarry. A. The outcrop situation in the basin of Genil; B. The outcrop aspect in the cutting of a path; C. Aspect of dolomitic marble after polishing and D. Surface of the quarry.

Between these triassic materials, there are also included various outcroppings of volcanic and subvolcanic rocks of basalt, dolerite and ophites type (Morata \& Puga 1993). As we stated above, we have identified the existence of exotic blocks, many with a low grade of metamorphism (prehnite-pumpellyite zone). The metamorphism can be observed in green sub-schist and, in some cases, the greenschist facies. However, some of the blocks with white ribbon marbles can present a higher grade of metamorphism (Perez-Valera et al., 2011).

The site of Cortijo Cevico is part of Complex Gypsum and specifically a tectonic melange characterized by a set of blocks included in the matrix of gypsum (Figure 2.B). These exotic blocks could be related to both, Alpujárride and Maláguide Complex, or even to the frontal units (i.e. Unit of Pereila) within the Internal Zones of Betic Cordillera (PerezValera et al., 2011). This outcrop has an extension of $4500 \mathrm{~m}^{2}$ approximately.

The texture of these marbles is crystalline with a slight foliation and black and white veining. This foliation is not widespread in the whole rock. It is more compact and homogenous in between the laminations whose appearance can be comparable to a marble texture. The dolomite blocks degrade more easily, influenced by external geological agents, hence, their aspect in the outdoor materials is much more different than those in the fresh fractured rock or just polished (Figure 2.C). The archaeological record on the outcrop is formed by the remains of the raw materials extraction, the elaboration of the supports, the 
knapping of the preforms, and the hammers used in these activities. The outcrop surface is covered with remains of knapping, debris and blocks used for the extraction of the supports (Figure 2.D).

\section{Material and methods}

The work performed in the quarry has been the intensive surface prospection and the excavation of two trenches following the natural slope of the outcrop. The excavation carried out in the trenches developed one in the lower part of the outcrop with $1 \mathrm{x} 4$ meters and another at the top with $2 \times 4$ meters (Figure 3). The prospection and excavation of the quarry has allowed us to document and to analyse a set of 442 preforms (Figure 4), 23 hammers and 851 technical pieces (flakes, knapping blocks and wastes).

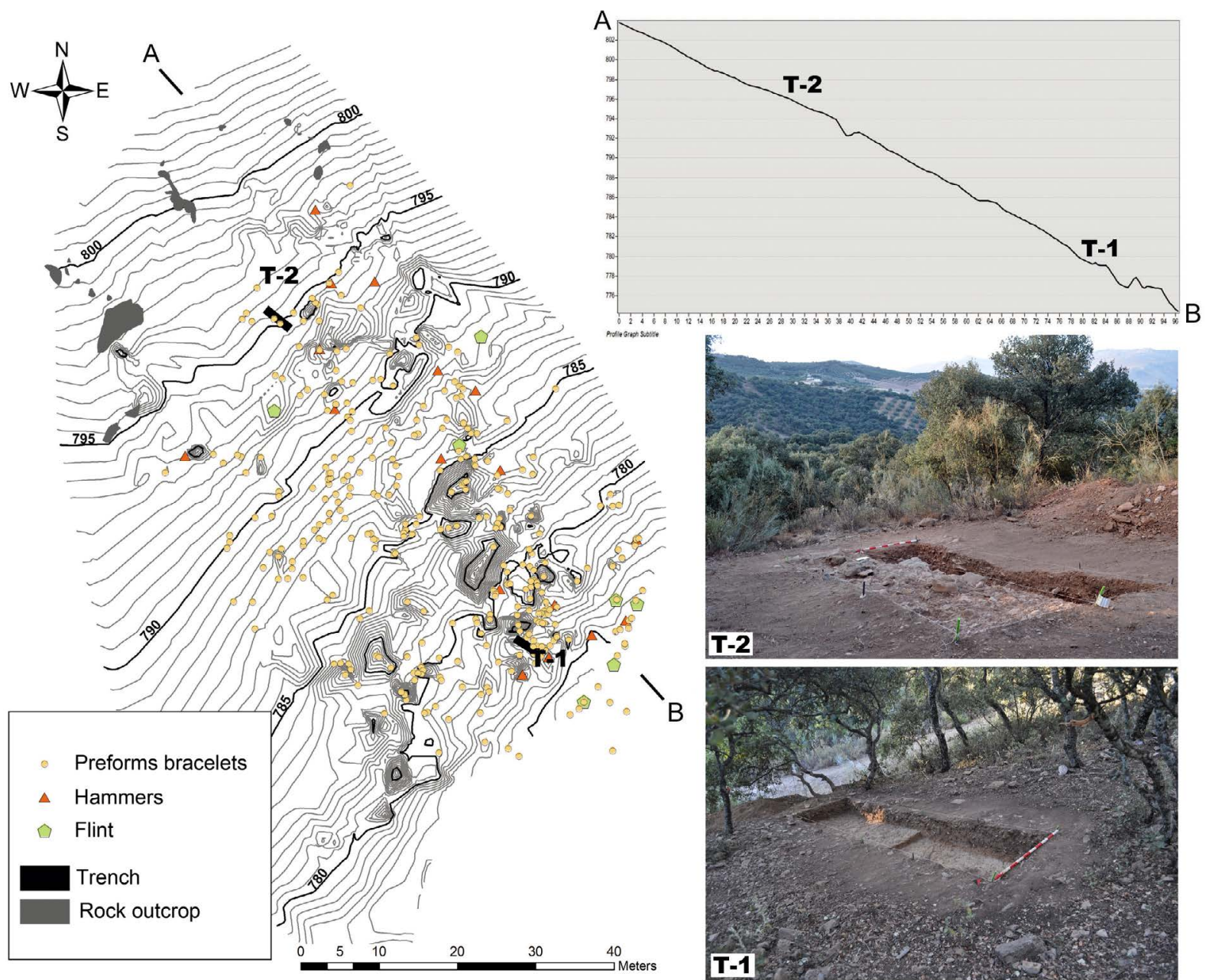

Figure 3. Superficial prospecting and two trenches excavated in relation with the slope.

The methodology used for the study of this material is based on the lithic technology, traceology, morphometry and experimentation as a reference (Baena \& Cuartero 2006; Odell 2004; Pelegrin 1990; Tixier et al., 1980: 29).

The experiments carried out have been knapping the preforms using the same raw material and hammers as those found in the quarry (Pelegrin 2011). The study of technical stigmas generated in the experimentation has been used parallel to its recognition in the archaeological remains (Figure 5.1). Likewise, the preforms knapping has allowed us to appreciate those needed skills for their elaboration and different breaks produced during this 
process (Figure 5.2). Experimental work in this kind of rock has not been done either from a quantitative or qualitative point of view, when focusing on the technological aspect.


Figure 4. Schematic explanation of the use of preforms to make bracelets. 1. Preform nearly finished and 2. Example of finished stone bracelet (settlement Cortijo Higuera Alta).


Figure 5. Experimental knapping of dolomitic marble. 1. Technical stigmata and 2. Example of knapping fail.

In the archaeological preforms, the reconstruction of the knapping scheme was performed by analysing diacritical schemes (Dauvois 1976). The analysis with a diacritical reading is based on the application of morphological and techno-mechanical criteria of the knapping object. Likewise, the organization and hierarchy of the removals can be recognized, as well as deducing the knapping scheme. Ordering the removals, we can establish the manufacturing process carried out in the elaboration of the object in a chrono-consequential way. Thus, identifying the criteria that allow orienting the removals and their overlays help us to reconstruct objectively the knapping series and to discern behavioural patterns. The elaboration of diacritical schemas is fundamental for the analysis of knapping tools, which global lecture as a whole allows us to interpret the reduction sequence and the chaîne opératoire at large scale (Shott 2003). Diacritical schemas represent the hierarchical chain of the scars preserved on the tool, and they are grouped into chromatic series where each colour defines different actions during knapping. This method of analysis has traditionally been applied to Paleolithic lithic assemblages (Baena et al., 2010; Baena et al., in press; Claud 2008; Chevrier 2012; Delagnes et al., 2007; Mourre 2003; Soriano 2000;) that have defined technological complexes that structure this period (Boëda et al., 1990; Boëda 1993; 
Bourguignon 1996; Delagnes 2000; Forestier 1993; Soressi 2004). In this studied case analyzed through a diacritical reading, the lithic analysis allows knowing what schemes and knapping techniques were employed to reduce the supports. In addition, it highlights the cultural significance of the analyzed produced because they are the result of a propositional reflection and voluntary on the decision in favor of a particular method (Pelegrin 1990).

Along these lines, we must understand lithic reduction processes as a necessary combination of a correct execution and knapping skill, where the two are indissolubly linked (Nonaka et al., 2010: 157). The ability to control all the factors involved in the execution of the knapping (knapping the surface shape and its relationship to the percussion platform, angle hitting, employed force and speed, weight and quality of the hammer, physical qualities of the raw materials, etc.) allows recognizing the knappers' expertise (Castañeda 2014: 342).

The use of this broad methodology in the Neolithic bracelets quarry is a great innovation because it is the first time that it is developed in the Iberian Peninsula and because of this, it opens a new research line.

\section{Results}

\subsection{Characterization the material remains of the bracelets quarry}

The superficial prospecting and excavation of the quarry has allowed us to identify the corresponding residues of quarrying activities and knapping. The studied material can be classified into the following categories:

- Preforms: These belong to the first stage of the elaboration of bracelets (Martínez-Sevilla \& Maeso 2011; Martínez-Sevilla 2013). The preforms are those left in the transformation process and they have not been used for some reason. We have divided them into five groups according to the cause of abandonment: 1. Medially fracture (Figure 6.1), 2. Longitudinal fracture (Figure 6.2), 3. Medially-longitudinal fracture, 4. Exceeded strike (Figure 6.3) and 5. Unviable preforms (Figure 6.4).

- Hammers: they are the only tools documented in the quarry. The most frequent lithology is the ophite and the marble found in the outcrop (obtaining the same percentage of ophite and marble as row material) and the only one element related with percussion is flint. The elements for percussion can be classified according to their weight into three groups: large size with more than 5000 g (Figure 7.1), albeit just one example of this type has been located; medium sized, weighing between 1000 and 2000 g (Figure 7.2); and the most common, small with less than $1000 \mathrm{~g}$ (Figure 7.3).

- Waste from the extraction and processing. At the same time, this group can be divided into:

- Knapping blocks: they can be considered core for the extraction of large flakes, from which the preforms are worked.

- Large flakes: they are one of the supports to make preforms (Figure 8.1). The large flakes documented are those that did not meet the necessary characteristics for its transformation. It is extracted through projecting percussion. The dimensions of the flakes vary; the length can be in between 10 and $15 \mathrm{~cm}$ and their width oscilates between 10 and $20 \mathrm{~cm}$, while the thickness is 4 to $6 \mathrm{~cm}$. The stigmas of knapping are marked and developed pseudo-bulbs. However, in many cases the bulb is not perceptible by the type of fracture in split. The presence of fracture type Siret is frequent because of the violent and perpendicular percussion. - Waste roughing: it consists of waste generated in the removing process of large flakes or the processing of natural blocks. They do not have a particular morphology or technical marks of knapping on many occasions.

- Knapping wastes: in this group the most characteristic element is the flakes product of knapping the preform. These can be classified into two types: percussion flakes, with marked bulbs, generally with a bigger width than length between 3 to $6 \mathrm{~cm}$ of length, and a 5 to 10 
mm of thickness (Figures 8.2 and 8.3); and preform flakes (Figure 8.4), where the circular curvature is observed and, often, no bulbs or other stigmata of knapping are observed.
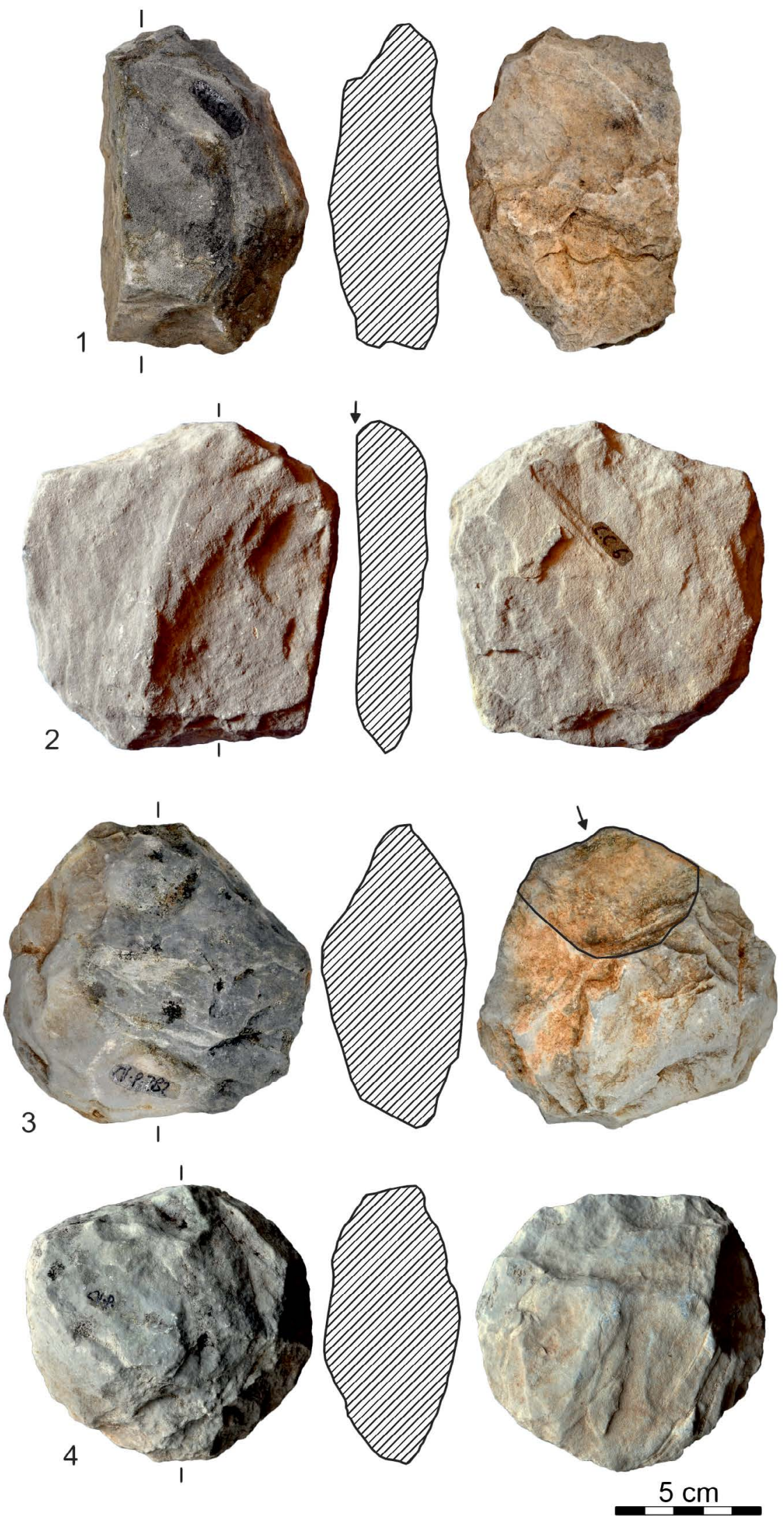

Figure 6. Different types of preforms documented in the quarry. 1. Medially fracture; 2. Longitudinal fracture; 3. Exceeded strike and 4. Unviable. (Scale bar is $5 \mathrm{~cm}$ wide.) 

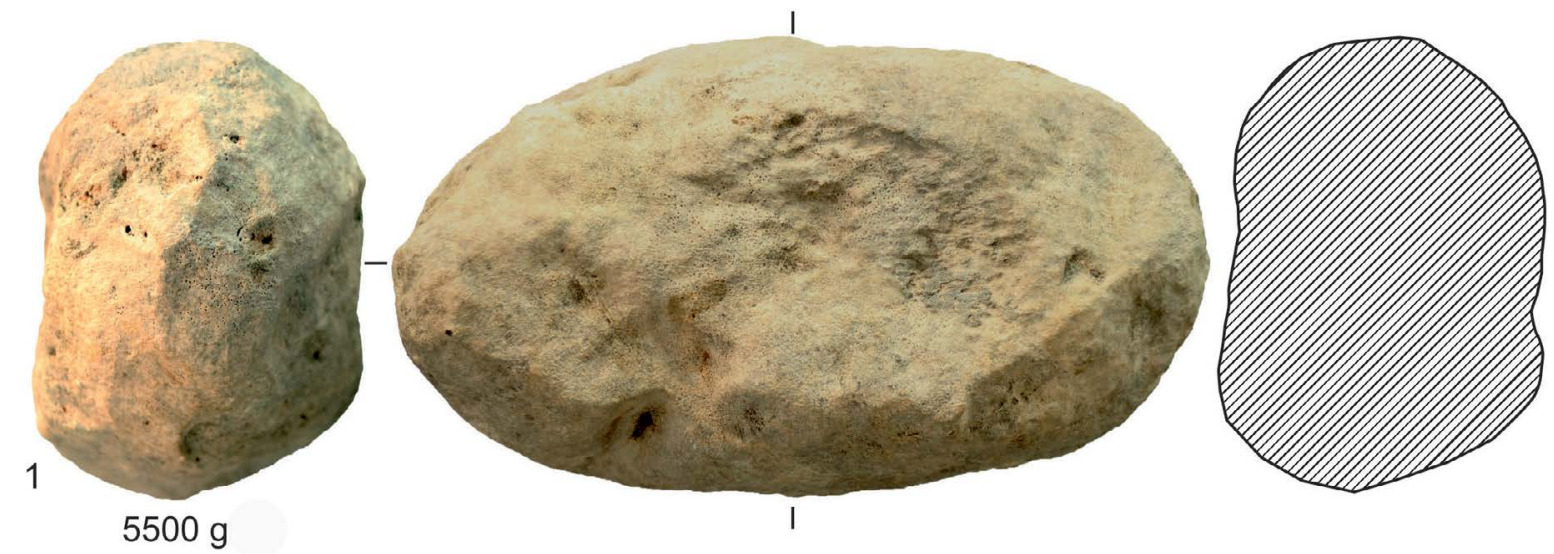

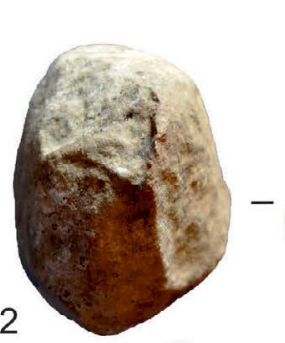

$973 \mathrm{~g}$



I

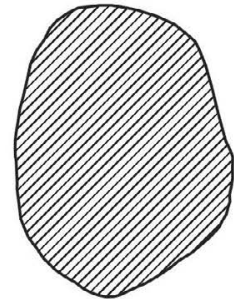

3

$247 \mathrm{~g}$
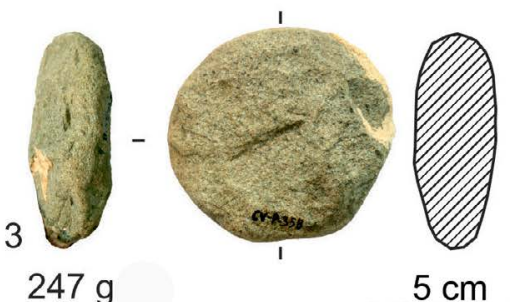

$-5 \mathrm{~cm}$

Figure 7. Different types of hammer defined in the quarry. 1. Huge hammer, more than 5kg; 2. Medium hammer, between 1 and $2 \mathrm{~kg}$ and 3. Small hammer, less than $1 \mathrm{~kg}$. (Scale bar is $5 \mathrm{~cm}$ wide.)

\subsection{Extraction of raw materials}

The extraction of raw material is closely related to the geological context in which the crafted blocks appear. At the beginning, the quarry could present a superficial use where the removed blocks from the geological context were extracted by natural processes like tectonic or erosion.

The rock is contained in gypsum like blocks, thus the most frequent system was digging the geological substrate. This technique has been documented in the excavation of the trench 2. This technique consists on open pits excavations because the raw material should have emerged next to the vegetative cover at the time of the quarry exploitation. The pits are between 50 and $60 \mathrm{~cm}$ depth and they probably correspond to marble blocks torn from the gypsum. We have not documented any tool that could be related to the activity of excavation. By analogy with other Neolithic mining contexts of flint in the Iberian Peninsula (Consuegra et al. 2007; Capote 2011; Capote Fernández 2013: 262; Castañeda 2014: 27), elements like antlers or simple digging sticks could have been used, given the shallowness of the pits and type of sediment.

\subsection{Obtaining supports and the knapping techniques}

Preforms are knapped mainly by two types of supports: natural marble blocks and large flakes. From the totality of the analyzed preforms, a $42 \%$ of the material remains undetermined regarding the source of the support. However, those determined pieces indicated that the supports most used are the large flakes in a $40 \%$ and natural geological supports in a $16 \%$.

The extraction of large flakes must be related to the large knapped blocks by projecting percussion with larger hammers. The technique of projecting percussion for the extraction of large flakes has been documented for the elaboration of axe heads of ophites in a nearby outcrop (Morgado et al., 2013). In the case of marble, being a much softer material, direct 
percussion is used for its extraction with medium hammers. The method of exploitation of large cores is centripetal or a united front.
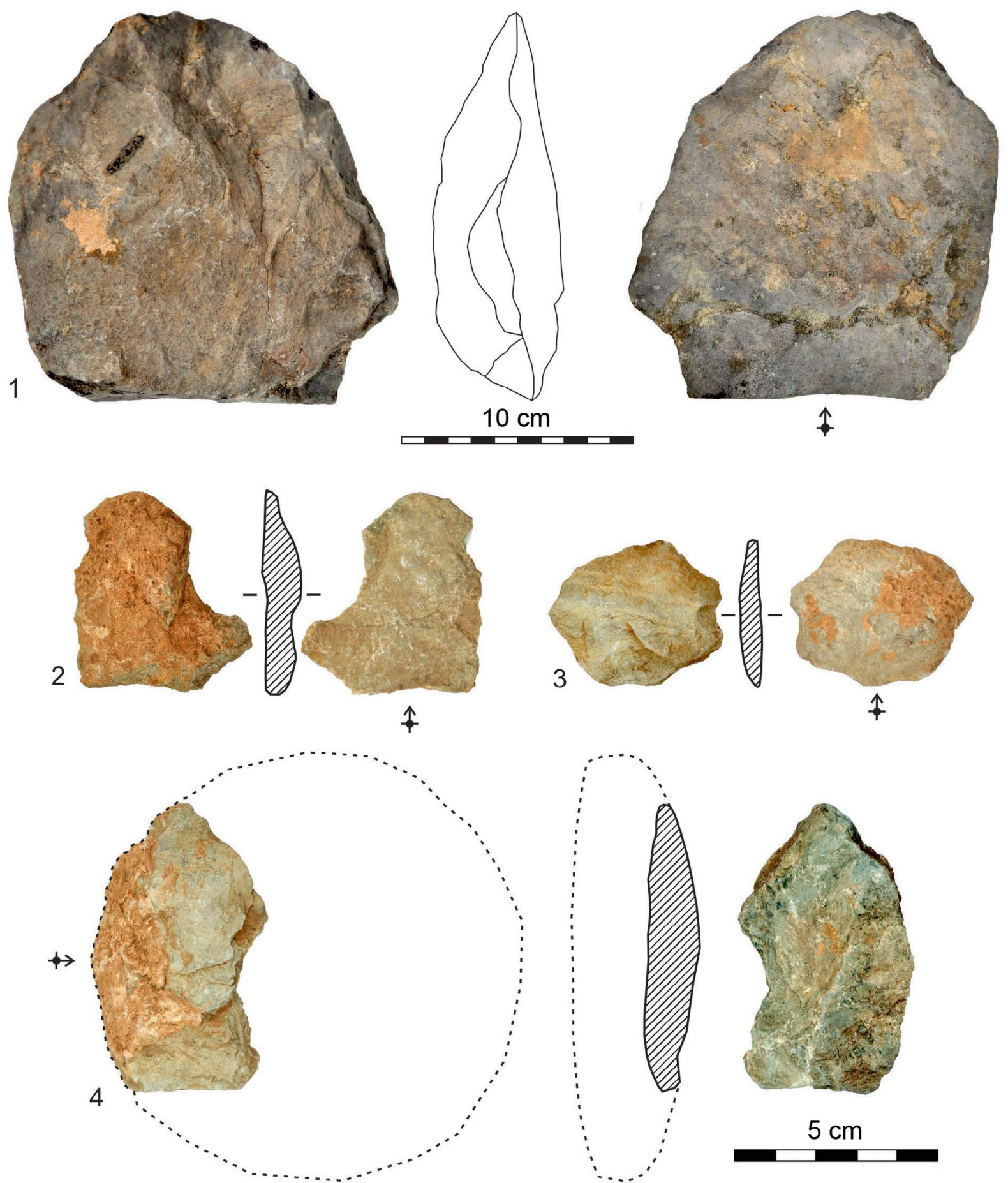

Figure 8. Different types of flakes determined in the quarry. 1. Large flake; 2 and 3. Percussion flakes; and 4. Preform flake.

We have identified direct percussion as the technique used for knapping the preforms. This process could be distinguished thanks to the experiments carried out and the study of the hammers and technical stigmas of knapping (Martínez-Sevilla 2010; Martínez-Sevilla \& Maeso 2011; Martínez-Sevilla 2013). The dolomite marble has textural characteristics with 
almost conchoidal fracture. However, because of the metamorphism suffered, this marble presents planar structures (foliation) and can present fracture planes.

The direct percussion is carried out with smaller and lighter hammers; hence they are the largest set with 18 pieces. The knapping is adapted to make the disc-shaped preforms. The percussion is executed obliquely or perpendicularly to the plane of percussion. The oblique is $45^{\circ}$ and it produces removals that form the circular shape, while the perpendicular is $90^{\circ}$ and it generates preform flakes for slimming down the thickness. Preform flakes can be produced also by a discontinuous plane of the dolomite and even potentially a longitudinal fracture of the preform.

\subsection{The knapping methods}

The reconstruction of knapping methods was based on the study of the abandoned preforms during the early stage of transformation. Here, there are some examples of diacritical schemes where the main methods of knapping are shown:

- Preform 463 (Figure 9): determining the type of support from which the preform has been configured has not been possible. The knapping is divided into two bifacial alternating series on the edges that relate alternately, an ascending and a descending. As it can be seen in the profile of the piece, the previous removals are used as striking platforms for the next removals.
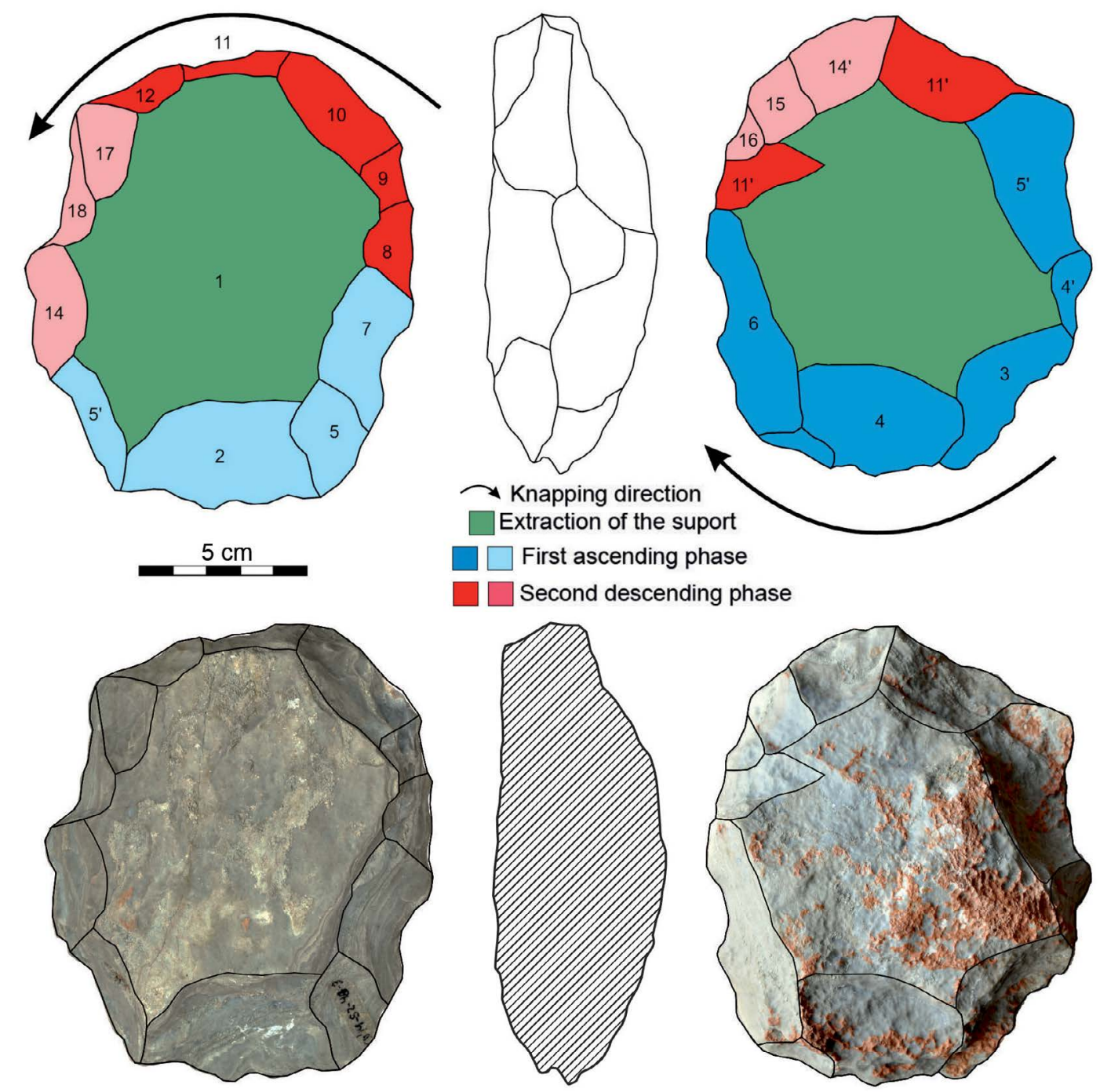

Figure 9. Diacritic scheme of knapping preform No. 463. 
- Preform 241 (Figure 10): the support is a large flake and the preform has been knapped taking the ventral face of it. The knapping is unifacial and it is organized into two centripetal ascending series that converge. The knapping is done directly, that is, the plane of percussion is always the ventral surface of the flake.
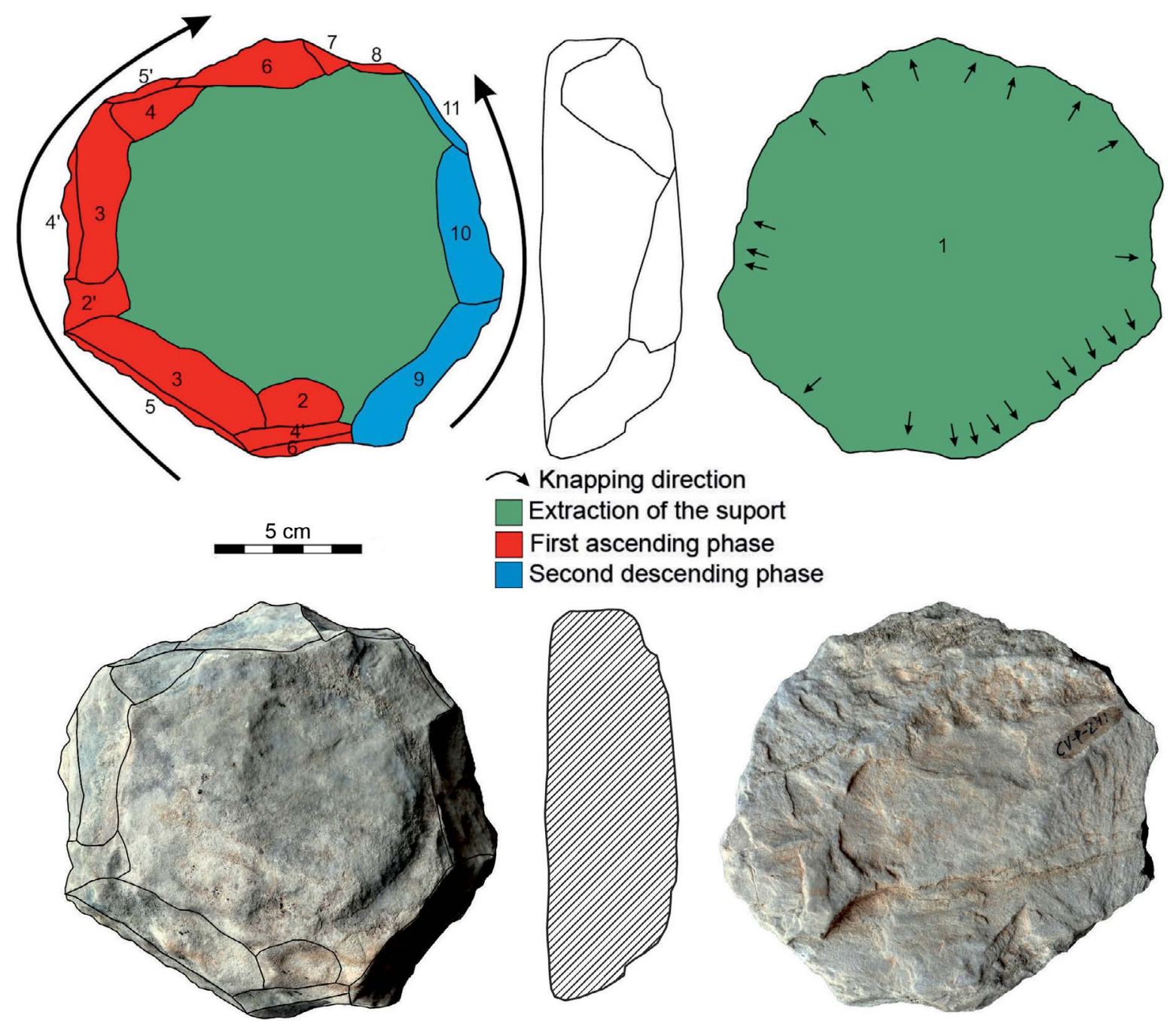

Figure 10. Diacritic scheme of knapping preform No. 241.

- Preform 239 (Figure 11): the support is a large flake. The knapping direction is divided into two bifacial alternating ascending series converging with each other. Side $A$ is the centripetal configuration of the support by thinning and side B, ventral face, is configured by extractions that serve as striking platform.

- Preform 162 (Figure 12): the support is a natural geological tablet. The knapping is divided into three separate series. The plane of percussion is the back of the tablet, so it cannot relate the series or determine whether the type of knapping is alternative or alternating bifacial. So, we have to define them as a series with an independent unipolar character. The removals of this series are intended to thinning the tablet and, in turn, to the pre-circular configuration of the support shape.

The most common knapping method is two series of removals. The direction may be one series ascending and another descending, ascending or two converging. The knapping of these series can be alternated and bifacial in groups of one to five strokes or unifacial, working independently each edge. The choice of one or the other is due to the morphology and volume of the support and to the intention of slimming the volume of the preform configured circular 
in shape. In some preforms it was observed the knapping on anvil, placing the preform on a support and perpendicular to the percussing edge. This type of technique is less controlled than those made with the piece in the hand and it might be related to a lower skill or learning processes.
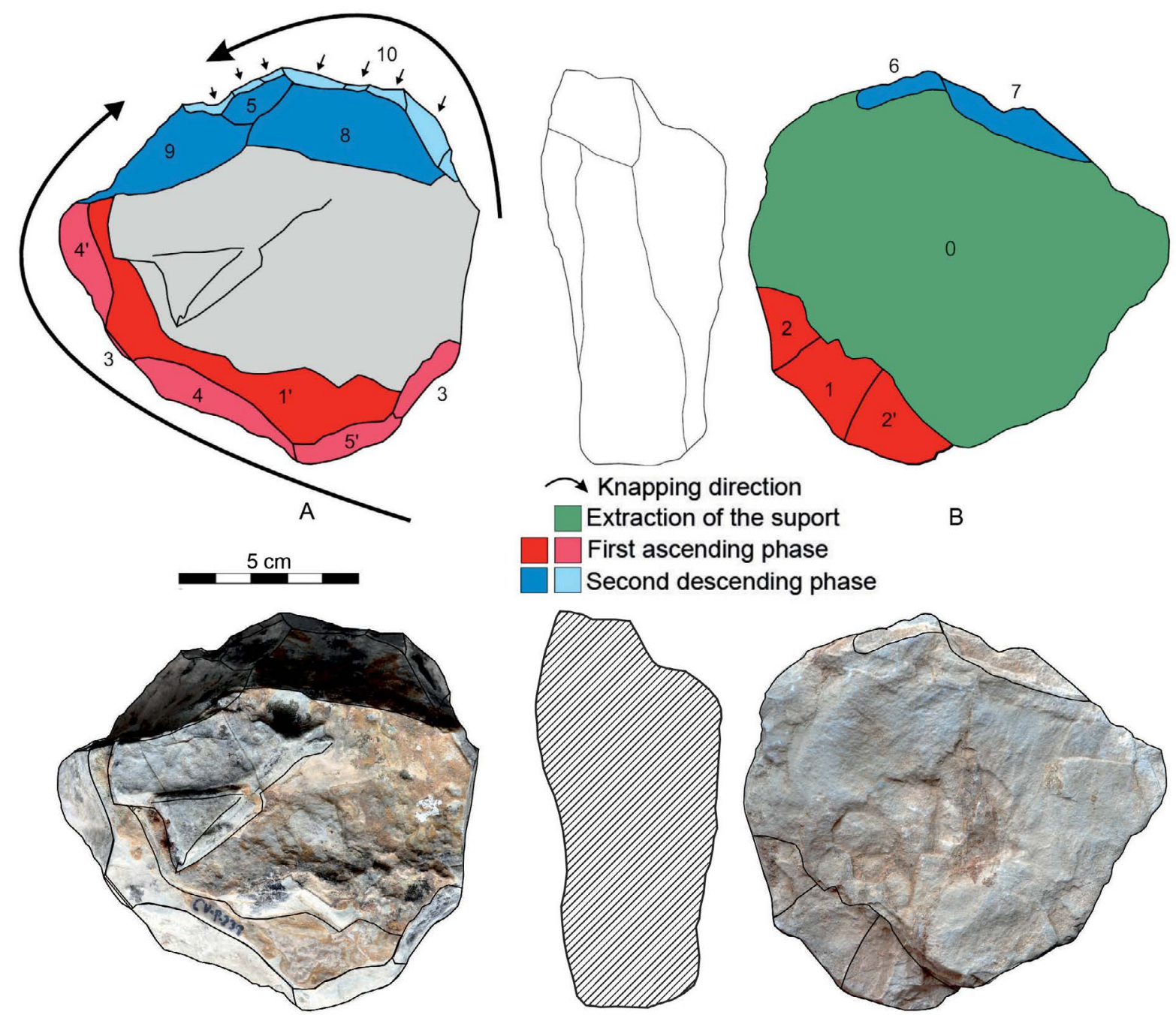

First ascending phase

Second descending phase
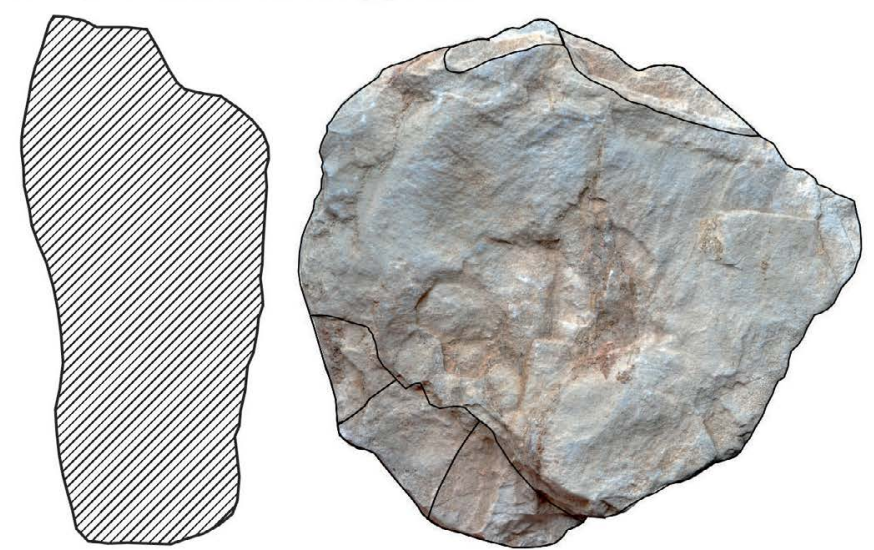

Figure 11. Diacritic scheme of knapping preform No. 239.

During the knapping process, the fractures and abandonment of the preforms are produced, which are a direct effect of the technical type and the raw material used (Figure 13). If we consider the discontinuous plane of the dolomite, longitudinal fractures in the natural planes should be the most numerous. However, they represent only $9 \%$ of the preforms abandoned. The low percentage of this group of fractures is determined by a careful selection of the homogeneity of the raw material without fracture planes. The most common breakage (with a $36 \%$ ) is in the central part of the pieces. This is due to the use of direct and violent percussion. The second largest group of abandoned preforms are considered in our classification as unviable (31\%). This percentage of discarded pieces can be related to three variables: first, the characteristics of the raw material; second, the impurities or discontinuous planes created out of the knapping process, discarding the preform; third, an inadequate size, the inability to form a preform with specific measures forces the abandonment. Within this group, it can be highlighted how the preforms continue their knapping even if the measures and the raw material is not ideal. In this sense, it might develop learning processes in the quarry and these preforms are, perhaps, the reflects of this. In general, the set of materials and 
the knapping stigmata indicate that the artisans were highly skilled in the execution of the knapping. Nevertheless, a careless execution is also related to the abundance of raw materials and its easy access to it.
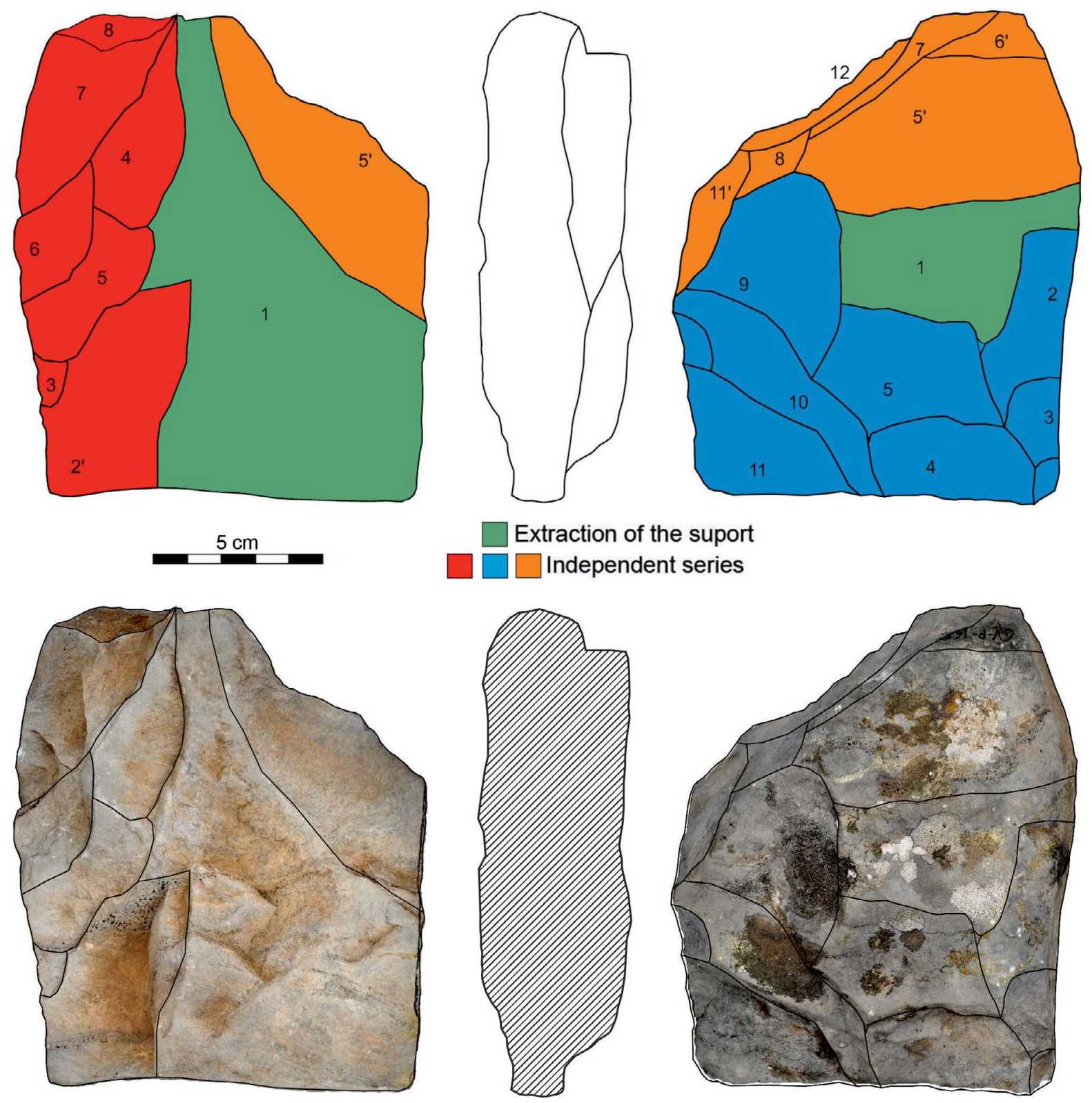

Figure 12. Diacritic scheme of knapping preform No. 162.

\section{Conclusions}

The extraction of raw materials and the first transformation by knapping those circular performs that make bracelets was conducted at the Cortijo Cevico. Accumulations of tested blocks, preforms and debitage, related to the extraction sites indicate that the elaboration of the preforms is synchronously performed to the extraction process. This is documented in other archaeological sites for the production of flint artefacts (Capote Fernández 2013: 247; Castañeda 2014: 27). The extraction of raw materials and the primary processing by knapping is done in the same context. Similarly, the layers of sediment with the extraction remaining and the knapping that intersects indicate different times of use in the excavation and the quarry. 


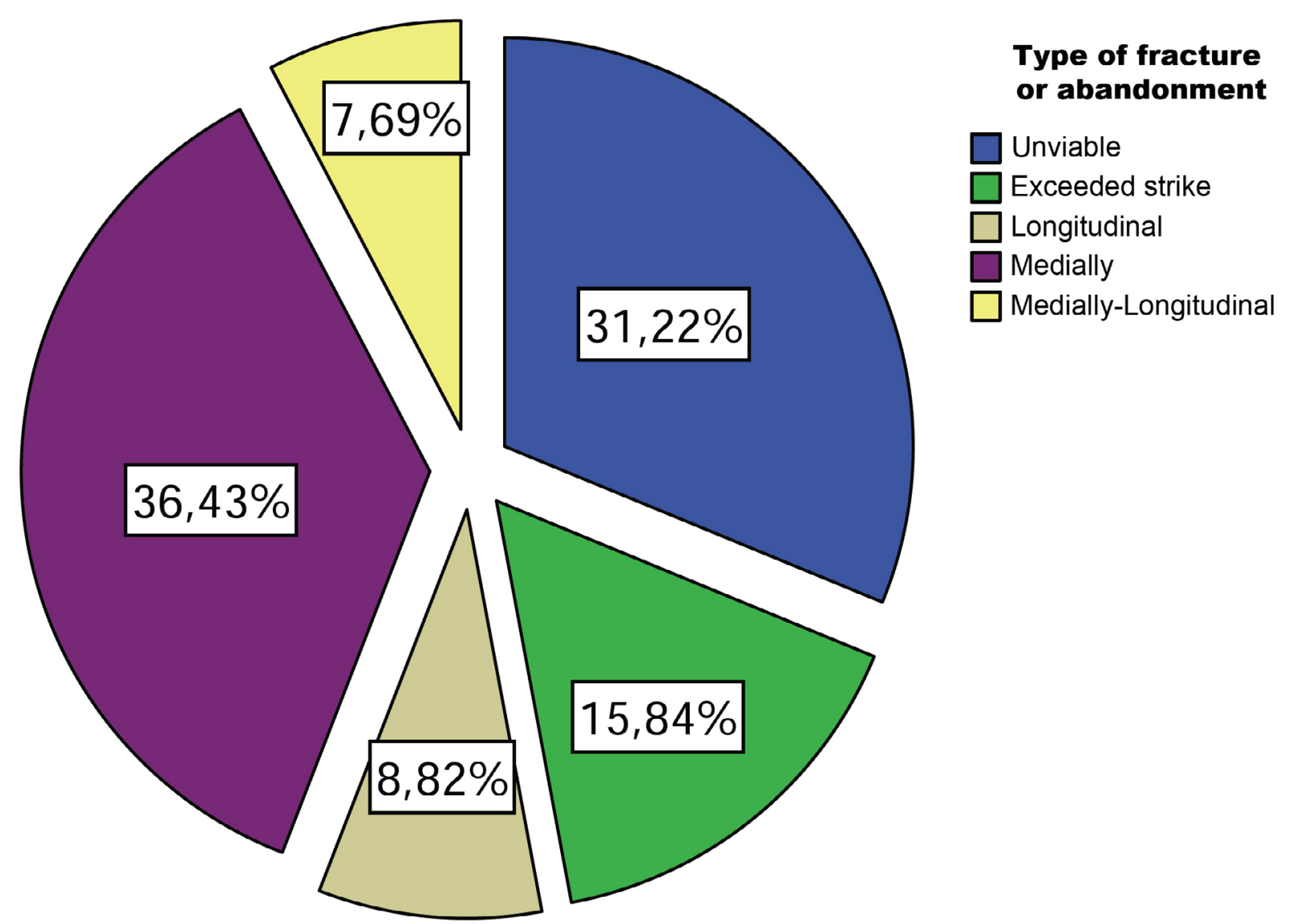

Figure 13. Percentages of the types of fractures or abandonment in the preforms.

The knapping techniques and methods are very homogeneous throughout the totality of the studied preforms. The set of materials with knapping traces indicates that the artisans are highly skilled in the execution of the knapping process. The ordination of removals, the percussion points and the size of the flakes show the knappers' skill (Adouze \& Cattin 2011; Brooke 2012; Castañeda 2014: 339; Hovers 2009; Nonaka et al. 2010). However, in some cases a careless execution is noted. This can be related to the abundance of raw materials and their easy access.

The use of the quarry should be sporadic and possibly expanded in time frequented by human groups of the immediate surroundings. This can be inferred from the absence of other materials different from other quarry wastes. Likewise, the absence of remains from other phases of the manufacturing process in the quarry must be related to occasional use. The other processing steps are documented in settlements (Martínez-Sevilla 2010; Carrasco et al. 2011; Martínez-Sevilla 2016). We do not consider the case of Cortijo Cevico intensive exploitation for the massive production of preforms. But rather, a place frequented at certain times to produce preforms that will be transformed into bracelets in the settlements. This outcrop must have been one of the several sites for this purpose around this area. Our expectations are to implement the knowledge about other quarries like Cortijo Cevico to contribute building a global view of the bracelets phenomenon in the Early Neolithic of the South of Iberian Peninsula.

\section{Acknowledgements}

The authors would like to thank Sofía Rojas Miguel for her collaboration during the experimentation phase, Beatriz Revelles Benavente for the translation of the paper and finally the anonymous referee for their suggestions that have improved this work. Besides, we would 
like to thank the funding offered for this research project by the research group Hum-143 of the Junta de Andalucía and the Department of Prehistory and Archaeology of the University of Granada.

\section{References}

Adouze, F. \& Cattin, M. 2011, Flint wealth versus scarcity: consequences for Magdalenian apprenticeship. Lithic Technology, 36: 109-126. doi:10.1179/lit.2011.36.2.109

Baena Preysler, J. \& Cuartero, F. 2006, Más allá de la tipología lítica: lectura diacrítica y experimentación como claves para la reconstrucción del proceso tecnológico. Zona Arqueológica, 7(1): 145-160. (in Spanish) ("Beyond the lithic typology: diacritical reading and experimentation as key to the reconstruction of the technological process")

Baena, J., Lordikpanidze, D., Cuartero, F., Ferring, R., Zhvania, D. Martín, D., Shelia, T., Bidzinashuili, G., Roca, M. \& Rubio, D. 2010, Technical and technological complexity in the beginning: the study of Dmanisi lithic assemblage. Quaternary International, 223: 45-53. doi:10.1016/j.quaint.2010.01.019

Baena, J., Moncel, M-H., Cuartero, F., Chacón Navarro, M.G. \& Rubio, D. in press, Late Middle Pleistocene génesis of Neanderthal technology in Western Europe: The case of Payre site (south-east France). Quaternary International, (in press, accepted 4 September 2014): 27 p. doi:10.1016/j.quaint.2014.08.031

Boëda, E., Geneste, J. M. \& Meignen, L. 1990, Identification des Chaînes Opératoires lithiques du Paléolithique Ancien et Moyen. Paléo, 2: 43-80. (in French) ("Identification of the lithic operational chains of the Early and Middle Palaeolithic") doi:10.3406/pal.1990.988

Boëda, E. 1993, Le debitage discoïde et le débitage levallois récurrent centripéte. Bulletin de la Société Prèhistorique Française, 90(6): 392-404. (in French) ("Discoid debitage and Levallois recurring centripetal scouring”) doi:10.3406/bspf.1993.9669

Bourguignon, L. 1996, La conception de débitage Quina. Quaternaria Nova, 6: 149-166. (in French) ("The conception of débitage Quina")

Brooke, S. 2012, Lithic raw material availability and Palaeo-Eskimo novice flintknapping. In: Archaeology and Apprenticeship, body knowledge, identity and communities of practice (Wendrich, W. Ed.), University of Arizona Press, Tucson: p. 119-144.

Capote, M. 2011, Working in the flint mine: Percussion tools and labour organisation at Casa Montero (Spain). In: Proceedings of the 2nd International Conference of the UISPP Commission on Flint Mining in Pre- and Protohistoric Times (Capote, M., Consuegra, S., Díaz-del-Río, P. \& Terradas, X., Eds.), British Archaeological Reports, International Series Vol. 2260, Archaeopress, Oxford: p. 231-242.

Capote Fernández, M. 2013, Trabajo y comunidad en el Neolítico antiguo: los útiles de percusión de la mina de sílex de Casa Montero, Doctoral thesis, Complutense University of Madrid, Madrid, 500 p. (in Spanish) ("Work and community in the ancient Neolithic: the percussion tools of the Casa Montero flint mine”)

URL: http://eprints.ucm.es/21868/1/T34568.pdf 
Carrasco Rus, J., Martínez-Sevilla, F. \& Gámiz, J. 2011, Algunas cuestiones sobre los asentamientos al aire libre del Neolítico Antiguo/Medio en "La Vega” de Granada. ANTIQVITAS, 23: 47-71. (in Spanish) ("Some questions about the outdoor settlements in Early/Middle Neolithic in "La Vega" of Granada") URL: https://dialnet.unirioja.es/descarga/articulo/3739598.pdf.

Carvalho, A. F., Peña-Chocarro, L. \& Gibaja Bao, J. F. 2010, Datación directa de cebada (Hordeum vulgare L.) de la cueva de Los Mármoles (Córdoba, España). Promontoria, 15: 247-249. (in Spanish) ("Direct dating of barley (Hordeum vulgare L.) from the cave of Los Mármoles (Córdoba, Spain)”) URL: http://hdl.handle.net/10261/85824

Castañeda, N. 2014, El trabajo del silex. La mina del Neolítico Antiguo de Casa Montero (Madrid) y su Sistema técnico, Doctoral thesis, Complutense University of Madrid, Madrid, 588 p. (in Spanish) ("The work of the silex. The old Neolithic mine of Casa Montero (Madrid) and its Technical System”) URL: http://hdl.handle.net/10486/661865

Cámalich Massieu, M.D. \& Martín Socas, D. 2013, Los inicios del Neolítico en Andalucía. Entre la tradición y la innovación. Menga. Revista de Prehistoria de Andalucía, 4: 103132. (in Spanish) ("The beginnings of Neolithic in Andalusia. Between tradition and innovation")

Consuegra, S., Díaz-del-Río, P., Castañeda, N., Criado, C. \& Capote, M. 2007, La minería de sílex en Casa Montero. Aspectos Tecnológicos. In: Actas de las Segundas Jornadas de Patrimonio Arqueológico en la Comunidad de Madrid. (Alcalá de Henares, 2005). Dirección General de Patrimonio Histórico, Consejería de Cultura y Turismo, Comunidad de Madrid, Madrid: p. 189-194. (in Spanish) ("Flint mining at Casa Montero. Technological Aspects”) URL: http://hdl.handle.net/10261/10322

Chevrier, B. 2012, Les assemblages à pièces bifaciales au Pléistocène inférieur et moyen ancien en Afrique de l'est et au Proche-Orient. Novelle aproche du phénomène bifacial appliquée aux problematiques de migrations, de diffusion et d'evolution locale. Doctoral thesis, University of Paris Ouest Nanterre La Defense, Paris, 864 p. (in French) (“Assemblages with bifacial pieces in Lower and Early Middle Pleistocene in East Africa and Near East: new approach of the bifacial phenomenon applied to the issues of migrations, diffusion and local evolution”) URL: http://www.theses.fr/2012PA100115

Claud, É. 2008, Le statut fonctionnel des bifaces au Paléolithique moyen récent dans le SudOuest de la France. Étude tracéologique intégrée des outillages des sites de La Graulet, La Conne de Bergerac, Combe Brune 2, Fonseigner et Chez-Pinaud/Jonzac. Doctoral thesis, University of Bordeaux 1, Bordeaux, 546 p. (in French) (“The functional status of bifaces in the Middle Paleolithic in the southwest of France. Integrated tracing of tooling of the sites La Graulet, La Conne de Bergerac, Combe Brune 2, Fonseigner et Chez-Pinaud/Jonzac”) URL: https://hal.archives-ouvertes.fr/tel-00361290/

Dauvois, M. 1976, Précis de dessin dynamique et structural des industries lithiques préhistoriques. Pierre Fanlac - Centre national de la recherche scientifique (CNRS), Périgueux, 263 p. (in French) ("Precis of dynamic and structural drawing of prehistoric lithic industries”) URL: http://trove.nla.gov.au/version/12969909

Delagnes, A. 2000, Blade production during the Middle Paleolithic in Northwestern Europe. Acta Anthropologica Sinica, Beijing, (Proceeding of 1999 Beijing International Symposium on Paleoanthropology) 19: 181-188. 
Delagnes, A., Jaubert, J. \& Meignen, L. 2007, Les technocomplexes du Paleolithique Moyen en Europe Occidentale dans leur cadre diachronique et géographique. In: Les Neandertaliens. Biologie et cultures (Vandermersch, B \& Maureille, B., Eds.), Editions du CTHS: p. 213-229. (in French) ("Technocomplexes of the Middle Paleolithic in Western Europe in their diachronic and geographical framework") URL: https://hal.inria.fr/halshs-00185692/document

Fromont, N. 2013, Anneaux et cultures du néolithique ancien: production, circulation et utilisation entre massifs ardennais et armoricain. British Archaeological Reports, International Series 2499, Archaeopress, Oxford, 723 p. (in French) (“Rings and cultures of the old Neolithic: production, circulation and use between Ardennes and Armorican massifs”)

Fromont, N., Maingaud, A., Coutard, S., Leclerc, G., Bohard, B., Thomas, Y. \& Charraud, F. 2006, Un site d'acquisition du schiste pour la fabrication d'anneaux au Néolithique ancien à Saint-Germain-du-Corbéis “ l'Ermitage ” (Orne). Bulletin de la Société préhistorique française, 103(1): 49-70. (in French) ("A site for the acquisition of shale for the manufacture of rings in the old Neolithic at Saint-Germain-du-Corbéis "l'Ermitage" (Orne)”) URL: http://www.jstor.org/stable/41220954

Forestier, H. 1993, Le Clactonien: mise en application d'une nouvelle méthode de débitage s’inscrivant dans la variabilité des dystemes de production lithique du Paléolithique Ancien. Paléo, 5: 53-82. (in French) ("The Clactonian: application of a new method of cutting that is part of the variability of the dystemes of lithic production of the Ancient Palaeolithic”) doi:10.3406/pal.1993.1104

Foucault, A. 1966, Le diapirisme des terrains triasiques au Secondaire et au Tertiaire dans le Subbetique du NE de la province de Grenade (Espagne meridionale). Bulletin de la Societe Geologique de France, 8: 527-536. (in French) ("The diapirism of triassic terrains in the Secondary and Tertiary in the Subbetic of the NE of the province of Granada (Southern Spain)”)

Hovers, E. 2009, Learning from mistakes: flaking accidents and knapping skills in the assemblage of A. L. 894 (Hadar, Ethiopia). In: The Cutting Edge: New Approaches to the Archaeology of Human Origins (Schick, K. \& Toth, N. Eds.): p 137-150. URL: http://www.stoneageinstitute.org/pdfs/cutting-edge-ch7-hovers.pdf

Martinez-Sevilla \& Salmerón Juan, J. 2014, La artesanía de los brazaletes líticos de la CuevaSima de la Serreta (Cieza, Murcia): Tecnología, útiles y funcionalidad del sitio. Zephyrus, 74: 65-87. (in Spanish) ("The crafts of the stone bracelets in the Cueva-Sima de La Serreta (Cieza, Murcia): technology, tools and functionality of the site”) doi:10.14201/zephyrus2014746587

Martínez-Sevilla, F. 2010, Un taller neolítico de brazaletes de piedra en la cueva de los Mármoles (Priego de Córdoba). ANTIQVITAS, 22: 35-55. (in Spanish) (“A Neolithic workshop of stone bracelets in the cave of Mármoles (Priego de Córdoba)”) URL: https://dialnet.unirioja.es/descarga/articulo/4456821.pdf.

Martínez-Sevilla, F. 2013, La tecnología de elaboración de los brazaletes anchos de piedra neolíticos del sur de la Península Ibérica. In: Experimentación en arqueología. Estudio y difusión del pasado (Palomo, A., Piqué, R., \& Terradas, X., Ed.), Sèrie Monogràfica del MAC 25.1, Museu d’Arqueologia de Catalunya, Girona: p. 87-96. (in Spanish) ("The technology of elaboration of the neolithic wide stone bracelets of the south of the Iberian Peninsula”) 
Martínez-Sevilla, F. 2014, Los contextos de producción de brazaletes de piedra neolíticos en el Sur de la Península Ibérica y sus implicaciones socioeconómicas. In: II Congreso de Prehistoria de Andalucía (15-17 febrero 2012, Antequera, Málaga) (García, E., Ed.), Junta de Andalucía Consejería de Educación, Cultura y Deporte, Antequera: p. 303-313. (in Spanish) ("The production contexts of Neolithic stone bracelets in the South of the Iberian Peninsula and their socioeconomic implications”)

Martínez-Sevilla, F. 2016, Un adorno reflejo de una sociedad. Los brazaletes líticos del Neolítico de Iberia (VI-V milenio a.C.). Tecnología, funcionalidad y circulación. Doctoral thesis. University of Granada, Granada, 638 p. (in Spanish) (“An ornament as reflection of society. The stone bracelets in the neolithic of Iberia $\left(6^{\text {th }}-5^{\text {th }}\right.$ millennium BC) Technology, functionality and circulation”)

Martínez-Sevilla, F. \& Maeso Taviro, C. 2011, Tecnología para la elaboración de brazaletes líticos de sección plana en el Neolítico del Sur de la Península Ibérica desde la experimentación. In: Investigación experimental aplicada a la Arqueología (Morgado, A., Baena, J. \& García, D., Ed.): p.131-139. (in Spanish) (“Technology of flat section stone bracelets in the Neolithic South of the Iberian Peninsula from experimentation”)

Micheli, R. 2012, Raw materials, personal ornaments and Neolithic groups: some observation on stone bracelets of the Early Neolithic of Northern Italy. RUBRICATUM, 5: 241-248. URL: http://www.raco.cat/index.php/Rubricatum/article/view/270078/

Morata, D \& Puga, E. 1993, Los piroxenos de las doleritas triásicas (“Ofitas”) de las zonas externas de las cordilleras béticas como indicadores petrogenéticos. Boletín de la Sociedad Española de Mineralogía, 16: 175-187. (in Spanish) ("The pyroxenes of the Triassic dolerites ("Ofitas") of the outer zones of the bética ridges as petrogenetic indicators")

Morgado, A., Martínez-Sevilla, F. \& Lozano, J.A. 2013, Tallar para pulir. Experimentación sobre la elaboración de hachas pulimentadas de rocas ofíticas en el sur de la península ibérica. In: Experimentación en arqueología. Estudio y difusión del pasado (Palomo, A., Piqué, R., \& Terradas, X., Ed.), Sèrie Monogràfica del MAC, Girona: p. 109-118. (in Spanish) ("Knapping for polishing. Experimentation on the elaboration of polished axes of ophitic rocks in the south of the Iberian peninsula")

Mourre, V. 2003, Implications culturelles de la technologie des hachereaux. Doctoral thesis, University of Pris X-Nanterre. Paris, (3 Vols.), 895 p. (in French) ("Implications of the technology of the hachereaux”) URL: http://hachereau.pagesperso-orange.fr/texte.htm

Nonaka, T., Bril, B. \& Rein, R. 2010, How do stone knappers predict and control the outcome of flaking? Implications for understanding early stone tool technology. Journal of Human Evolution, 59: 155-167. doi:10.1016/j.jhevol.2010.04.006

Odell, G. H. 2004, Lithic analysis, Kluwer Academic/Plenum, New York, 261 p.

Pelegrin, J. 1990, Prehistoric lithic technology: Some aspects of research. Archaeological Review from Cambridge, 9(1): 116-125.

Pelegrin, J. 2011, Las experimentaciones aplicadas a la tecnología lítica. In: Investigación experimental aplicada a la Arqueología (Morgado, A., Baena, J. \& García, D., Eds.), Universidad de Granada and Uniervsidad Autónoma de Madrid, Ronda: p. 31-35. (in Spanish) ("Experimentations applied to the lithic technology") 
Pérez-López, A. \& Pérez-Valera, F. 2003, El diapirismo como factor esencial de resedimentación de las rocas del Triásico durante el Terciario en las zonas externas de la cordillera Bética. Geotemas, 5: 189-193. (in Spanish) ("The diapirismo as an essential factor of sedimentation of the rocks of the Triásico during the Tertiary in the external zones of the Bética mountain range”)

Pérez Valera, F., 2005, Estratigrafía y tectónica del Triásico Subibérico en el sector oriental de la Cordillera Bética. Doctoral thesis. Universidad de Granada, Granada, 237 p. (in Spanish) ("Stratigraphy and tectonics of the Subiberic Triassic in the eastern sector of the Betic Cordillera”) URL: http://hera.ugr.es/tesisugr/1544417x.pdf

Perez-Valera, F., Lozano, J.A., \& Perez-Valera, L.A. 2011, On the origin of the metamorphic exotic blocks located in the "Trías de Antequera" (Spain). In: Sixième reunion du Permien et du Trías, Groupe Marocain du Permien et du Trias, Tétouan: p. 36-37.

Pétrequin, P., Cassen, S., Chevillot, C., Errera, M., Pailler, Y., Pétrequin, A-M., Prichystal, A. \& Prodéo, F. 2015, La production des anneaux-disques alpins pedant les VI et V millénaires a.v, J.-C. et Le Mont Viso. In: L’homme et son environnement: des lacs, des montagnes et des rivières (Rey, P-J \& Dumont, A., Eds.), $40^{\text {ème }}$ supplément à la Revue Archéologique de l'Est, Dijon: p. 259-302. (in French) ("The production of the Alpine rings-disk during the $6^{\text {th }}$ and $5^{\text {th }}$ millennia BC. and Le Mont Viso")

Peña-Chocarro, L., Pérez Jordá, G., Morales Mateos, J. \& Vera Rodríguez, J.A. 2013,...y llegaron los agricultores: agricultura y recolección en el occidente del Mediterráneo. Menga. Revista de Prehistoria de Andalucía, 4: 15-33. (in Spanish) (“... and farmers arrived: farming and gathering in the western Mediterranean”)

Ruíz Taboada, A. \& Montero, I. 1999, Ocupaciones neolíticas en Cerro Virtud: Estratigrafía y Dataciones. Saguntum Extra (II Congrés del Neolític a la Península Ibèrica. Universitat de València), 2: 207-211. (in Spanish) ("Neolithic occupations in Cerro Virtud: Stratigraphy and dating”) URL: https://ojs.uv.es/index.php/saguntumextra/article/view/2823/

Sanz de Galdeano, C., Lozano, J.A. \& Puga, E. 2008, El “Trías de Antequera”: Naturaleza, origen y estructura. Revista de la Sociedad Geológica de España, 21(3-4): 111-124. (in Sapnish) ("The "Trías de Antequera": Nature, origin and structure") URL: http://www.sociedadgeologica.es/archivos/REV/21(3-4)/art02.pdf

Shott, M. J. 2003, Chaîne opératoire and reduction sequence. Lithic Technology, 28(2): 95105. doi:10.1080/01977261.2003.11721005

Soressi, M. 2004, From the Mousterian of Acheulian Tradition Type A to Type B: A change in technical tradition, raw material, task or settlement dynamics?. In: Settlement Dynamics of the Middle Paleolithic and Middle Stone Age (Conrad, N.J., Ed.), 2 Vols., Kerns Verlag, Tübingen: p. 343-366.

Soriano, S. 2000, Outillage bifacial et outillage sur éclat au Paléolithique ancien et moyen: coexistence et interaction. Doctoral thesis, University of Paris X, Nanterre, 460 p. (in French) ("Bifacial tools and flake tools of lower and middle Palaeolithic: coexistence and interaction")

Tixier, J., Inizan, M.L. \& Roche, H. 1980, Préhistoire de la pierre taillée I. Terminologie et technologie. Circle de Recherches et d'Études Préhistoriques, Valbonne, 200 p. (in French) ("Prehistory of knapping stone I. Terminology and technology") 